\title{
Determination the concentration of radon in human urine using
}

\section{LR-115 detector}

\author{
Essam M. Rasheed
}

Department of Physics, College of Science, Al-Nahrain University, Baghdad, Iraq

E-mail: esam_esam777@yahoo.com

\begin{abstract}
In the present study twenty samples of human urine were taken from healthy male and female with different of: ages, occupation and place of residence. These samples were collected from the hospital to measure the concentration of radon gas in human urine by using one of solid state nuclear track detectors LR-115.

The results obtained of the concentrations of radon in healthy human urine are varying from $2.12 \times 10^{-3}$ Bq..$^{-1}$ to $4.42 \times 10^{-3}$ Bq..$^{-1}$ and these values are less than the allowed limits $12.3 \times 10^{-3}$ Bq. $1^{-1}$.
\end{abstract}

Key words

Urine, radon, LR-

115, track detector, alpha particles.

Article info.

Received: Dec. 2015

Accepted: Feb. 2016

Published: Sep. 2016



\section{Introduction}

Radiation and radiation emitters (radionuclides) can expose the whole body (direct exposure) or expose tissue inside the body when inhaled or ingested. Different types of radiation vary in their ability to damage different kinds of tissue. All kinds of ionizing radiation can cause cancer and other effects. The main difference in the ability of alpha particles, beta particles, gamma-rays and x-rays to cause health effects is the amount of energy they have, their energy determines how far they can penetrate into tissue, it also determines how much energy they are able to transmit directly or indirectly to tissues and the resulting damage [1]. The biological damage resulting from a given absorbed energy may be quite different for different tissues for these reasons, it is necessary to measure the radiation with an instrument and then translate it into response of tissue. Since different detectors do not have the same efficiency or sensitivity for all types of radiation and at all energies, there is no single instrument that can be used for alpha, beta and gamma [2]. 
The monitoring of trace metals in human urine plays an important role to gain a better understanding of sources of environmental contamination. However, human urine is a complex matrix containing high levels of urea, uric acid, proteins, fats, sodium, potassium, bicarbonate and chloride[3].

\section{Collection of the samples}

Twenty samples of human urine were taken from the hospital to measure the concentration of radon gas that emission from urine human, these samples are shown in Table 1.

Table 1: Urine human samples code.

\begin{tabular}{|c|c|c|c|c|}
\hline Code of sample & Gender & Age (years) & Occupation & Place of residence \\
\hline $\mathrm{U} 1$ & male & 32 & worker & Baghdad \\
\hline $\mathrm{U} 2$ & male & 44 & worker & Baghdad \\
\hline $\mathrm{U} 3$ & male & 45 & worker & Basrah \\
\hline $\mathrm{U} 4$ & male & 65 & pensioned military man & Baghdad \\
\hline U5 & male & 20 & worker & Basrah \\
\hline U6 & male & 22 & farmer & Baghdad \\
\hline $\mathrm{U} 7$ & male & 27 & driver & Basrah \\
\hline U8 & male & 17 & student & Basrah \\
\hline U9 & male & 40 & driver & Baghdad \\
\hline U10 & male & 66 & pensioned officer & Baghdad \\
\hline U11 & female & 23 & student & Baghdad \\
\hline $\mathrm{U} 12$ & female & 33 & worker & Ramadi \\
\hline U13 & female & 45 & worker & Basrah \\
\hline U14 & female & 03 & housewife & Baghdad \\
\hline U15 & female & 20 & student & Baghdad \\
\hline U16 & female & 35 & worker & Basrah \\
\hline U17 & female & 25 & housewife & Baghdad \\
\hline U18 & female & 29 & housewife & Ramadi \\
\hline U19 & female & 50 & housewife & Ramadi \\
\hline U20 & female & 55 & housewife & Ramadi \\
\hline
\end{tabular}

\section{Experimental details}

The human urine samples were collected about 0.1 litter and stored for one month at normal laboratory conditions which were kept in plastic containers. This time is necessary to get a radiological equilibrating to the samples, before determining the concentration of natural radioactive material for the sample. Sheets of LR115 were cut into small pieces each one of $\left(1 \times 1 \mathrm{~cm}^{2}\right)$ area, then we put the track detector LR-115 into inner cover side of cylindrical container for two months to registries $\alpha$-particles tracks that emitted from radon gas as shown in Fig1. 


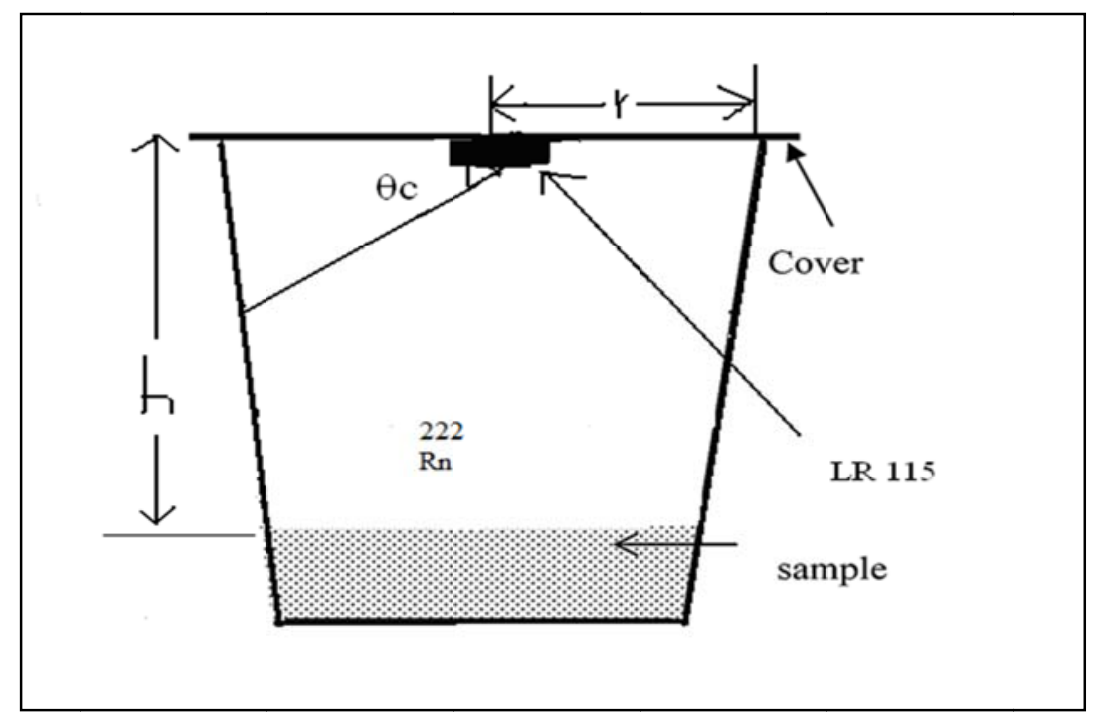

Fig.1: LR-115 detector with sample in the container.

After two months of the exposure, LR115 detectors were etched for (2.30) hr using chemical etching $(\mathrm{NaOH})$ solution with $(6.25 \mathrm{~N})$ at $55^{\circ} \mathrm{C}$, the etched detectors were washed by distilling water then dried and count the number of tracks under an optical microscope. The tracks in these samples that observed using LR-115 track detector as shown in Fig. 2.

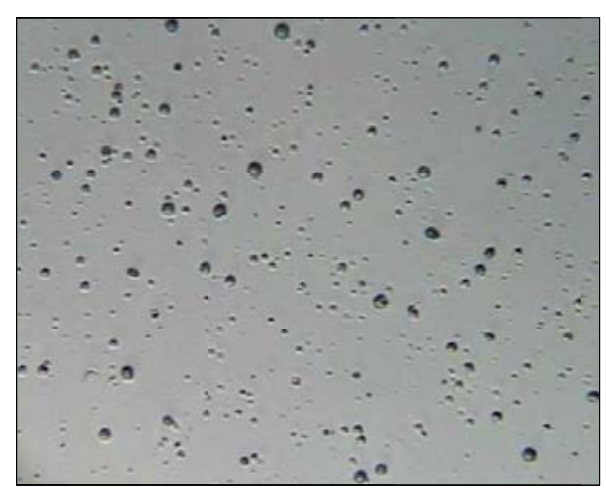

Fig.2: Image of LR-115 after etching.

\section{Results}

The concentration of radium begins to increase with time (t) according to the Eq. (1) [4]:

$\mathrm{C}_{\mathrm{Rn}}=\mathrm{C}_{\mathrm{Ra}}\left(1-\mathrm{e}^{-\lambda \mathrm{t}}\right)$

where $\lambda$ is the decay constant of radon and $\mathrm{C}_{\mathrm{Ra}}$ is the effective radium content of the sample (Bq. $1^{-1}$ ), since the plastic track detector LR-115 measures the time integrated value of the above expression, the total number of alpha disintegrations in unit volume of tube with calibration factor $\mathrm{K}$ during the exposure time $(\mathrm{t})$, hence the track density is given by [5]:

$\rho=\left(\mathrm{K} * \mathrm{C}_{\mathrm{Rn}} * \mathrm{~T}_{\text {eff }}\right)$

The radon concentration $\mathrm{C}_{\mathrm{Rn}}$ of integrated radon exposure inside the tube was obtained from the track density of the detector, by using the calibration factor

$\mathrm{K}=(0.034 \pm 0.002)$ tracks.cm ${ }^{2} /$ d. $\left(\right.$ Bq. $\left.\mathrm{m}^{3}\right)$ [6].

$\mathrm{T}_{\text {eff }}$ which is the effective exposure time and equal to the flowing equation: 
$\mathrm{T}_{\text {eff }}=\mathrm{t}-\tau\left(1-\mathrm{e}^{-\lambda \mathrm{t}}\right)$

where $\tau$ is the mean life of radon and equal to (5.5 days).

In this study the actual exposure time (t) is 60 days and the effective exposure time is: $\mathrm{T}_{\mathrm{eff}}=\mathbf{5 6 . 5}$ days.

It is clear that the effective radium content of the sample can be calculated from the flowing formula: [7,8]

$\mathrm{C}_{\mathrm{Ra}}=(\rho / \mathrm{K} * \mathrm{~T}$ eff $) *(\mathrm{~h} * \mathrm{~A} / \mathrm{V})$

where A: the area of the cross section of the tube in $\mathrm{m}^{2}$ and equal to $\left(0.00785 \mathrm{~m}^{2}\right)$. $\mathrm{h}$ : the distance between the detector and the top of the sample and equal to $(0.17 \mathrm{~m}) . \mathrm{V}$ : the volume of the sample in liter and in this study equal to (0.1 liter).

All of these procedures were completed at normal condition without using heating or cooling. To determine the concentration of radon we used the Eq.(1).

The radon concentration in all samples (Bq. $1^{-1}$ ) are shown in Table 2 and Fig.3.

Table 2: Radon concentration of urine human samples.

\begin{tabular}{|c|c|c|}
\hline code of sample & $\rho \operatorname{tracks} / \mathrm{cm}^{2}$ & $\mathrm{C}_{\mathrm{Rn}} \times 10^{-3} \quad$ Bq. $1^{-1}$ \\
\hline U1 & 722.85 & 2.58 \\
\hline $\mathrm{U} 2$ & 684.56 & 2.45 \\
\hline U3 & 920.63 & 3.30 \\
\hline $\mathrm{U} 4$ & 1020.74 & 3.66 \\
\hline U5 & 1232.75 & 4.42 \\
\hline U6 & 680.63 & 2.43 \\
\hline U7 & 950.34 & 3.40 \\
\hline $\mathrm{U} 8$ & 1100.22 & 3.95 \\
\hline U9 & 740.28 & 2.65 \\
\hline U10 & 890.66 & 3.20 \\
\hline U11 & 650.23 & 2.32 \\
\hline U12 & 876.24 & 3.15 \\
\hline U13 & 955.34 & 3.43 \\
\hline U14 & 590.66 & 2.12 \\
\hline U15 & 667.95 & 2.40 \\
\hline U16 & 1050.27 & 3.78 \\
\hline U17 & 780.44 & 2.80 \\
\hline U18 & 798.55 & 2.87 \\
\hline U19 & 840.20 & 3.02 \\
\hline U20 & 860.49 & 3.09 \\
\hline
\end{tabular}




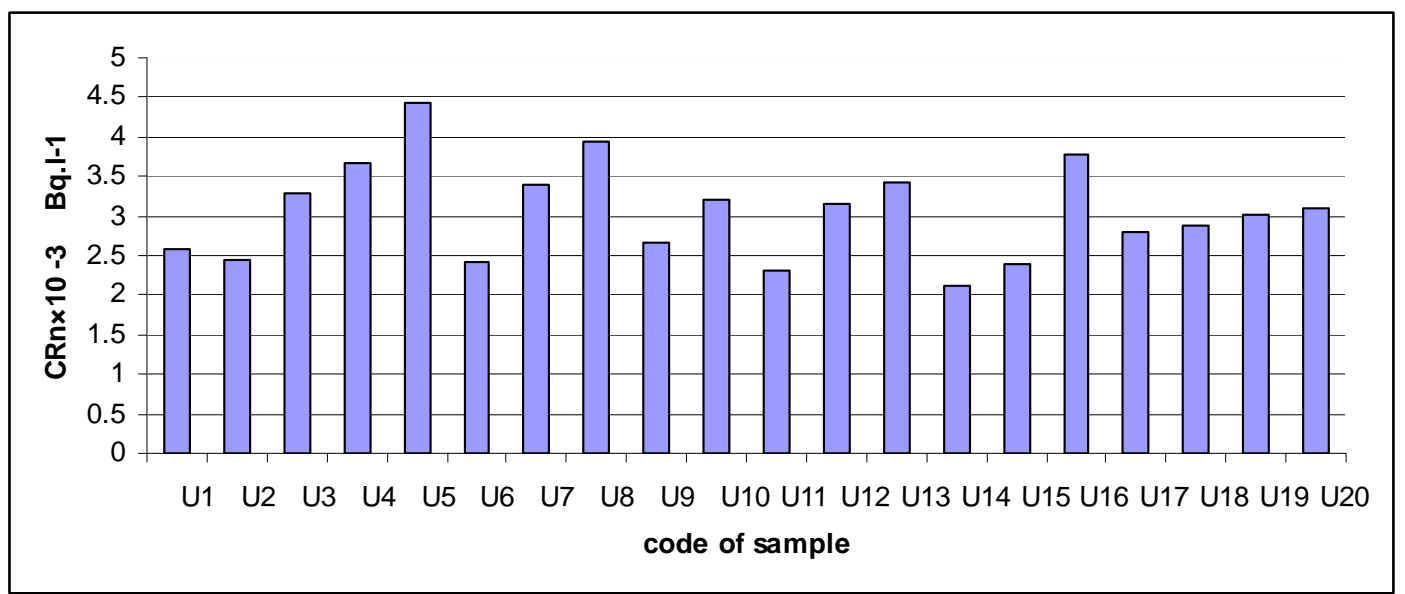

Fig.3: Radon concentration in all urine human samples.

The radon concentration in male urine samples are shown in Table 3 and Fig.4.

Table 3: Radon concentration in male urine human samples.

\begin{tabular}{|c|c|}
\hline code of sample & $\mathrm{C}_{\mathrm{Rn}} \times 10^{-3}{\mathrm{~Bq} .1^{-1}}^{-1}$ \\
\hline $\mathrm{U} 1$ & 2.58 \\
\hline $\mathrm{U} 2$ & 3.30 \\
\hline $\mathrm{U} 3$ & 3.66 \\
\hline $\mathrm{U} 4$ & 4.42 \\
\hline $\mathrm{U} 5$ & 2.43 \\
\hline $\mathrm{U} 6$ & 3.40 \\
\hline $\mathrm{U} 7$ & 3.95 \\
\hline $\mathrm{U} 8$ & 2.65 \\
\hline $\mathrm{U} 9$ & 3.20 \\
\hline U10 & 3.204 \\
\hline Average & \\
\hline
\end{tabular}

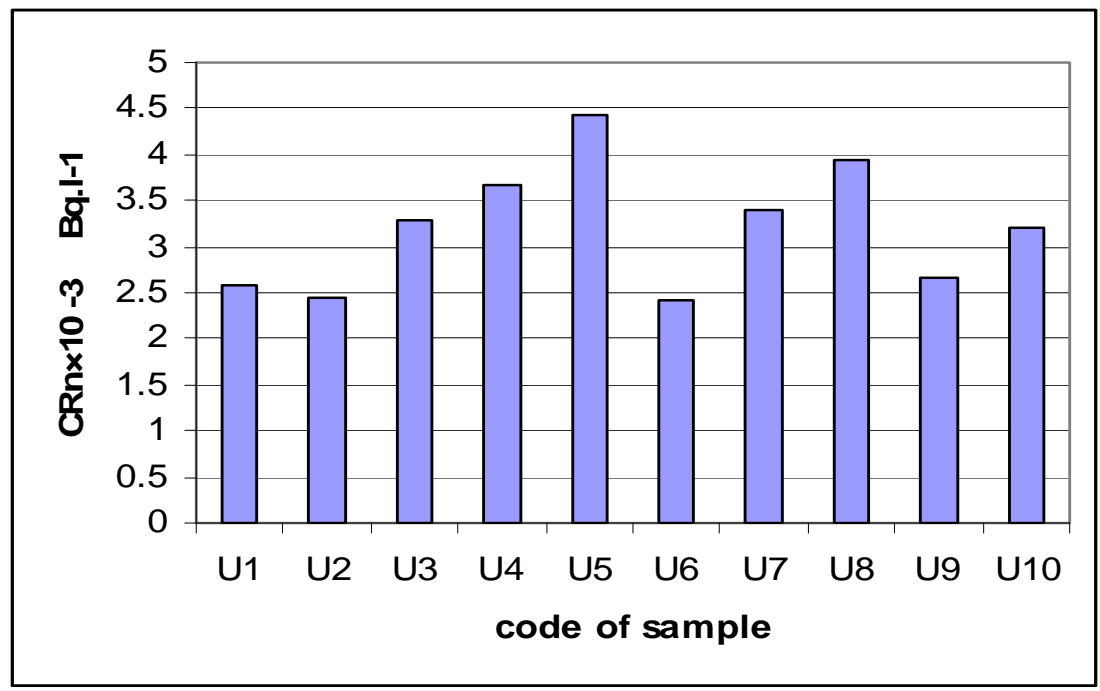

Fig. 4: Radon concentration of male urine human samples. 
The radon concentration in female urine samples are shown in Table 4 and Fig.5.

Table 4: Radon concentration in urine human of female samples.

\begin{tabular}{|c|c|}
\hline code of sample & $\mathrm{C}_{\mathrm{Rn}} \times{ }^{-3}$ Bq.1 $^{-1}$ \\
\hline $\mathrm{U} 11$ & 2.32 \\
\hline $\mathrm{U} 12$ & 3.15 \\
\hline $\mathrm{U} 13$ & 3.43 \\
\hline $\mathrm{U} 14$ & 2.12 \\
\hline $\mathrm{U} 15$ & 2.40 \\
\hline $\mathrm{U} 16$ & 3.78 \\
\hline $\mathrm{U} 17$ & 2.80 \\
\hline $\mathrm{U} 18$ & 2.87 \\
\hline U19 & 3.02 \\
\hline U20 & 3.09 \\
\hline Average & 2.89 \\
\hline
\end{tabular}

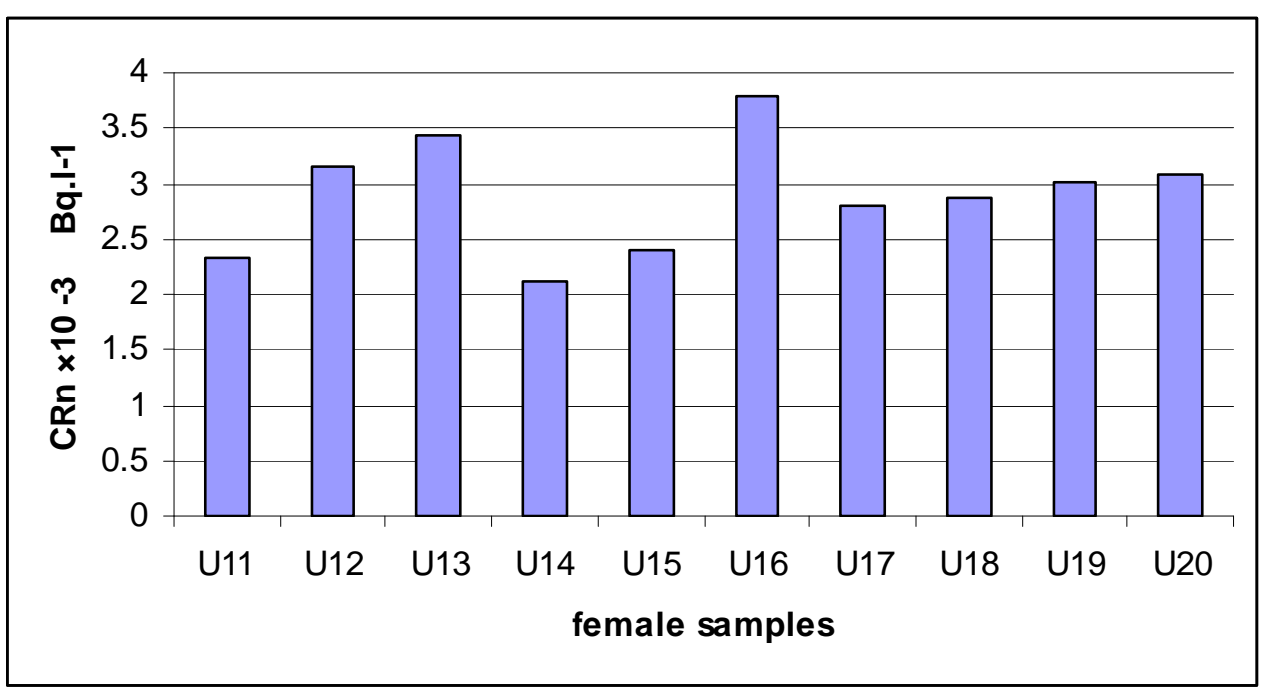

Fig. 5: Radon concentration of female urine human samples.

The difference between the average of radon concentration in male and female urine samples are shown in Fig.6. 


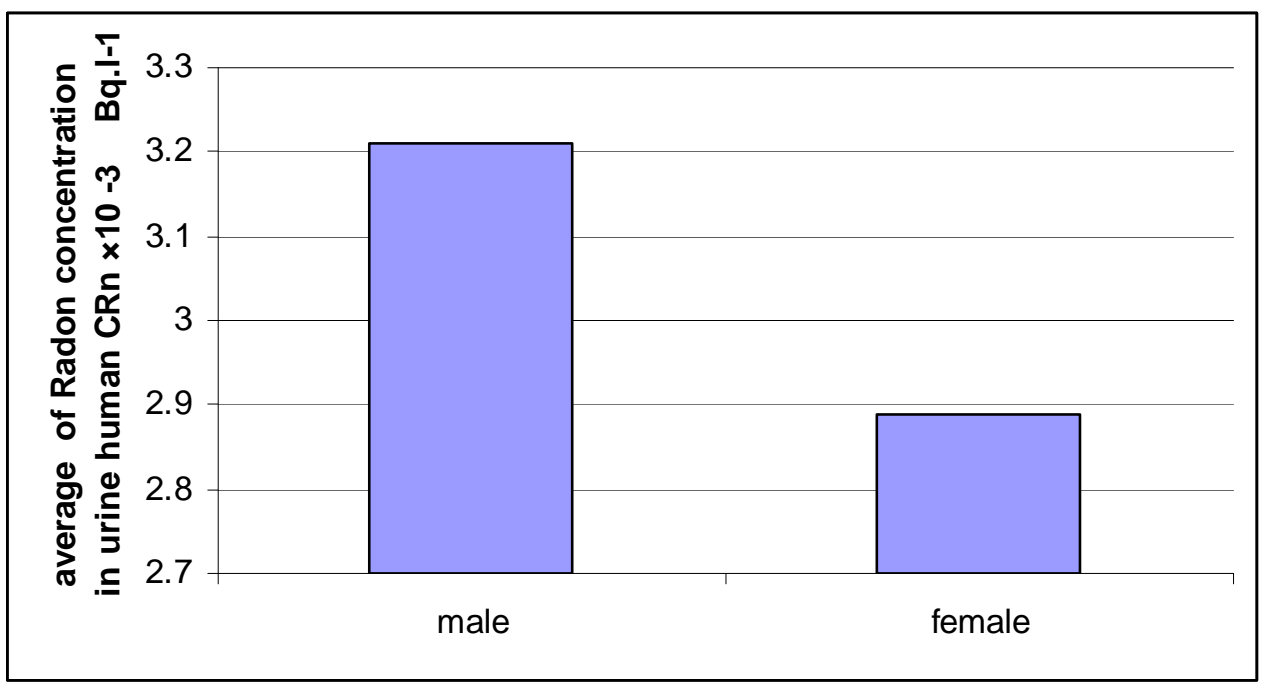

Fig.6: Average of radon concentration for male and female urine samples.

The radon concentrations in urine human of Baghdad samples are shown in Table 5.
The radon concentrations in urine human for Basrah samples are shown in Table 6.

Table 5: Radon concentration in urine human of Baghdad samples.

\begin{tabular}{|c|c|}
\hline Code of sample & $\mathrm{C}_{\mathrm{Ra}} \times 10^{-3}$ Bq. $^{-1}$ \\
\hline $\mathrm{U} 1$ & 2.58 \\
\hline $\mathrm{U} 2$ & 2.45 \\
\hline $\mathrm{U} 4$ & 3.66 \\
\hline $\mathrm{U} 6$ & 2.43 \\
\hline $\mathrm{U} 9$ & 2.65 \\
\hline $\mathrm{U} 10$ & 3.20 \\
\hline $\mathrm{U} 11$ & 2.32 \\
\hline $\mathrm{U} 14$ & 2.12 \\
\hline $\mathrm{U} 15$ & 2.40 \\
\hline $\mathrm{U} 17$ & 2.80 \\
\hline Average & 2.655 \\
\hline
\end{tabular}

Table 6: Radon concentration in urine human of Basrah samples.

\begin{tabular}{|c|c|}
\hline Code of sample & $\mathrm{C}_{\mathrm{Rn}} \times{ }^{-3}$ Bq.1 $^{-1}$ \\
\hline $\mathrm{U} 3$ & 3.3 \\
\hline $\mathrm{U} 5$ & 4.42 \\
\hline $\mathrm{U} 7$ & 3.40 \\
\hline $\mathrm{U} 8$ & 3.95 \\
\hline $\mathrm{U} 13$ & 3.43 \\
\hline U16 & 3.78 \\
\hline Average & 3.71 \\
\hline
\end{tabular}


The radon concentrations in urine human for Ramadi samples are shown in Table 7. The radon concentrations in urine human for Baghdad, Basrah and Ramadi samples are shown in Fig.7.

Table 7: Radon concentration in urine human of Ramadi samples

\begin{tabular}{|c|c|}
\hline Code of sample & $\mathrm{C}_{\mathrm{Rn}} \times 10^{-3} \quad$ Bq.1 $^{-1}$ \\
\hline $\mathrm{U} 12$ & 3.15 \\
\hline $\mathrm{U} 18$ & 2.87 \\
\hline $\mathrm{U} 19$ & 3.02 \\
\hline U20 & 3.09 \\
\hline Average & 3.032 \\
\hline
\end{tabular}

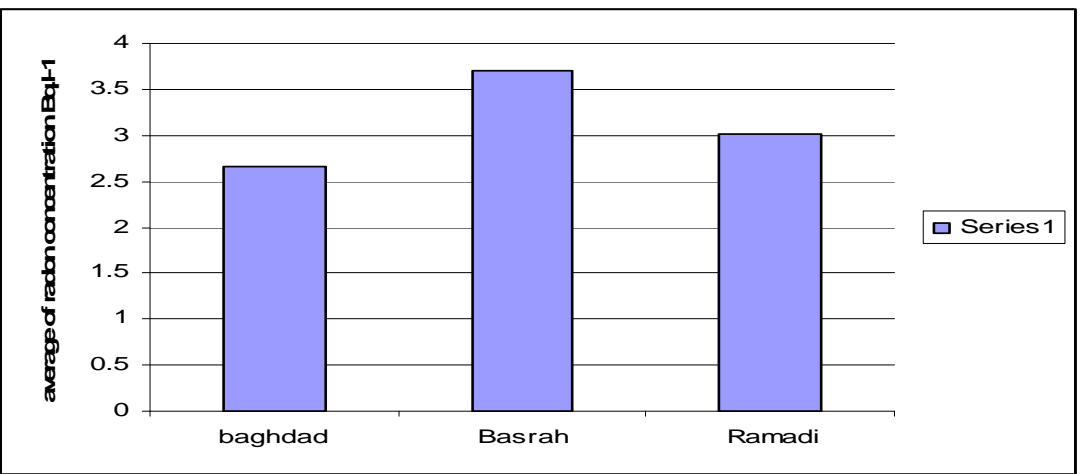

Fig.7: The average of radon concentrations in urine human for Baghdad, Basrah and Ramadi samples.

\section{Discussion}

From Table 2, the radon concentration in all urine human samples vary from $2.12 \times 10^{-3}$ Bq..$^{-1}$ to $4.42 \times 10^{-3}$ Bq..$^{-1}$, the minimum of radon concentration was in the sample U14- (female, 30year, housewife, Baghdad) and the maximum of radon concentration was in the sample U3- (male, 45year, worker, Basrah).

From Table 3, the radon concentration of urine human in male samples that vary from $2.43 \times 10^{-3} \quad$ Bq..$^{-1}$ to $4.42 \times 10^{-3}$ Bq..$^{-1}$, with the average of $3.21 \times 10^{-3}$ Bq. $1^{-1}$. The minimum of radon concentration of urine human in sample U6- (meal, 22 year, farmer, Baghdad) and the maximum of radon concentration of urine human was in sample U5- (male, 20year, worker, Basrah).

From Table 4, the radon concentration of urine human in female samples that vary from $2.12 \times 10^{-3} \quad$ Bq..$^{-1}$ to $3.78 \times 10^{-3}$ Bq. $1^{-1}$, with the average of $2.89 \times 10^{-3}$ Bq..$^{-1}$ The minimum of radon concentration of urine human in female was in sample U14-(female, 30years, housewife, Baghdad), the maximum of radon concentration of urine human in female was in sample U16-(female, 35 years, worker, Basrah).

From Table 3 and Table 4, we note that there is a difference of radon concentration in urine human between male and female samples because the radon concentration in urine human 
increased when the human is exposed for a long time to the radiation.

From Table 5 the radon concentrations of urine human in human samples where lived in Baghdad were varied from $2.12 \times 10^{-3}$ Bq. $1^{-1}$ to $3.66 \times 10^{-3} \mathrm{~Bq} .1^{-1}$, with the average of $2.66 \times 10^{-3}$ Bq. $1^{-1}$. The minimum of radon concentration of urine human was in sample U14- (female, 30years, housewife, Baghdad) and the maximum of radon concentration of urine human was in sample U4- (male, 65years, pensioned military man, Baghdad).

From Table 6, the radon concentrations of urine human in human samples where lived in Basrah were varied from $3.30 \times 10^{-3}$ Bq. $1^{-1}$ to $4.42 \times 10^{-3}$ Bq..$^{-1}$, with the average of $3.71 \times 10^{-3} \mathrm{~Bq} . \mathrm{l}^{-1}$. The minimum of radon concentration of urine human was in sample U5-(male, 20years, worker, Basrah) and the maximum of radon concentration of urine human was $\left(4.42 \times 10^{-3} \mathrm{~Bq}^{-1^{-1}}\right)$ in sample U3(male, 45years, worker, Basrah).

From Table 7, the radon concentrations of urine human in human samples where lived in Ramadi were varied from $2.87 \times 10^{-3}$ Bq. $1^{-1}$ to $3.15 \times 10^{-3}$ Bq..$^{-1}$, with the average of $3.01 \times 10^{-3}$ Bq. $1^{-1}$. The minimum of radon concentration in human's urine was in sample U18- (female, 29years, housewife) and the maximum of radon concentration of urine human was in sample U12-(worker, 29 years, housewife).

From Tables 5, 6 and 7, the average of radon concentration in humans urine from Baghdad samples is less than the radon concentration in human urine from Basrah samples because the radioactivity in Baghdad less than Basrah and the average of radon concentration of urine human from
Ramadi samples were between them because most areas of Ramadi contents a phosphate in soils and rocks.

\section{Conclusions}

From all the previous tables and results, the values of radon concentrations of urine human was dependence of the person's occupation, years of service, sex, age and health condition have been dealt with in sufficient details as required.

All these results are low compared with the allowed limit $12.3 \times 10^{-3} \mathrm{~Bq} . \mathrm{l}^{-1}$ [9].

\section{References}

[1] S.F. Hassan., "Determination of Uranium Concentration in Human Blood in Some Governorates of Iraq", M.Sc. Al- Nahrain University, 2006.

[2] A. F. A. Youssef and R. A. Farghli, Canad. J. Anal. Sci. Spec., 51 (2006) 288.

[3] J.Zhang, M. Chen, Ju, W. Z., Liu, S. J., Xu, M. J., Chu, J. H., Wu, T., J. Pharm. Biomed. Anal. 51 ( 2010) 685.

[4] P. Qu, Yan, S. C., Lu, H., Lu, Z. H., Microchim. Acta, 163 (2008) 321.

[5] B. X.Li, Guo, L. L., Xu, C. L., Ma, L. M., Spectrochim. Part, A 71 (2008) 892.

[6] A.A Ensafi, T.Khayamian, F.Hasanpour, J. Pharm. Biomed. Anal. 48 (2008) 321

[7] E.Nalewajko, A.Wiszowata, Kojło, A. J. Pharm. Biomed. Anal., 43 (2007) 210.

[8] B. Kozlowska, A. Walencik, J. Dorda, T. A. Przylibski, Radiat. Meas., 42 (2007) 1380.

[9] UNSCEAR "Sources, effects and risks of ionization radiation", United Nations Scientific Committee on the Effects of Atomic Radiation, Report to the General assembly, with Annexes, New York, p 34-40, 1993. 